\title{
WIESŁAW CHARCZUK
}

\section{„JEŚLI CHODZI O SPRAWE POLSKĄ (...). ROZWIĄŻEMY JE TAK, JAK HITLER SPRAWĘ ŻYDOWSKĄ. CHYBA, ŻE USUNĄ SIĘ SAMI"1}

w związku z książką Grzegorza Motyki Od rzezi wołyńskiej do akcji "Wisła”. Konflikt polsko-ukraiński 1943-1947, Wydawnictwo Literackie, Kraków 2011, 524 strony (wydanie pierwsze, dodruk w 2014)

DOI: $10.15290 /$ sp.2015.23.13

W 2011 r. na polskim rynku księgarskim ukazała się praca Grzegorza Motyki, w której stara się ukazać stosunki polsko-ukraińskie, w najtragiczniejszym okresie dla obu narodów w XX w. Narody polski i ukraiński zostały okrutnie doświadczone represjami zarówno ze strony komunizmu, jak i nazizmu. Przez długie dziesięciolecia komuniści starali się wymazać z pamięci społecznej ofiary wielkich zbrodni, jak Wielki Głód na Ukrainie z lat trzydziestych XX w., czy zbrodnię w Katyniu. Dopiero po upadku komunizmu Polacy i Ukraińcy mogli otwarcie mówić o tragicznych losach swoich narodów. Wśród Polaków żywa jest pamięć o masowych mordach na Polakach na Wołyniu i w Galicji Wschodniej, które popełnili Ukraińcy spod znaku OUN-UPA. Z kolei naród ukraiński doświadczył traumatycznych przeżyć w ramach komunistycznej operacji akcji „Wisła”, w której przymusowo wysiedlono Ukraińców w 1947 r. z Polski południowo-wschodniej na tereny Polski zachodniej, by łatwo ulegli asymilacji. Praca ma układ chronologiczno-problemowy. Data początkowa nie budzi zastrzeżeń, wiosną 1943 r. nasiliły się ataki Ukraińców na Polaków, wzrosła liczba śmiertelnych ofiar po stronie polskiej, zaś akcja prowadzona przez oddziały UPA przybrała znamiona

1 Wypowiedź jednego z dowódców UPA, [w:] G. Motyka, Od rzezi wołyńskiej do akcji "Wisła”. Konflikt polsko-ukraiński 1943-1947, Kraków 2011, s. 126-127. 
czystki etnicznej. W swojej książce Autor wykorzystał materiały zdeponowane w 14 archiwach, m.in. w polskich, ukraińskich, rosyjskich i białoruskich: w Instytucie Polskim i Muzeum im. gen. W. Sikorskiego w Londynie, Centralnym Państwowym Archiwum Wyższych Organów Władzy i Administracji Ukrainy, Narodowym Archiwum Białorusi, Państwowym Archiwum Służby Bezpieczeństwa Ukrainy, Centralnego Państwowego Archiwum Społecznych Organizacji Ukrainy, Archiwum Wschodnim, Archiwum Akt Nowych, Państwowym Archiwum Obwodu Lwowskiego, Rosyjskim Państwowym Archiwum Wojennym, Państwowym Archiwum Federacji Rosyjskiej, Centralnym Archiwum Wojskowym w Warszawie, Archiwum Instytutu Pamięci Narodowej, Archiwum Państwowym w Warszawie i Archiwum Państwowym w Rzeszowie.

Cezura końcowa książki zamyka się na roku 1947, kiedy dzień po śmierci gen. Karola Świerczewskiego 29 marca 1947 r. Biuro Polityczne PPR podjęło w trybie przyśpieszonym decyzję o rozpoczęciu akcji wysiedleńczej pod kryptonimem „Wisła”, która miała objąć ludność ukraińską. W ten sposób komuniści chcieli dokonać ostatecznego rozwiązania problemu ukraińskiego w Polsce. Książka zawiera wstęp noszący tytuł Do czytelników, 28 rozdziałów, przypisy, wybraną bibliografię, źródła do ilustracji, indeks nazwisk i indeks miejscowości. Pracę otwiera rozdział poświęcony problemowi ukraińskiemu na progu odzyskania niepodległości przez Polskę w listopadzie 1918 r. W tym rozdziale Autor ukazał walki Polaków o Lwów w listopadzie 1918 r., które dały początek konfliktowi polsko-ukraińskiemu w czasie wojny polsko-bolszewickiej w latach 1919-1920. Pokój ryski nie zamknął sprawy ambicjonalnej Ukraińców do stworzenia niepodległego państwa ukraińskiego. Dla młodego państwa polskiego element ukraiński zamieszkujący Wschodnią Galicję stanowił poważny problem. W $1931 \mathrm{r}$. Galicję Wschodnią zamieszkiwało 60\% ludności, która deklarowała się jako ukraińska i tylko 28,5\%, która przyznawała się do narodowości polskiej². Stąd wiadomo, jaki byłby ewentualny wynik plebiscytu dla Polski. Władze II RP zdawały sobie sprawę z takiego zagrożenia. Również strona ukraińska nie zamierzała czekać z „założonymi rękoma”. Latem 1920 r. została utworzona tajna Ukraińska Organizacja Wojskowa, na której czele stanął płk Jewhen Konowalec.

Można powiedzieć, że niewypowiedziana wojna polsko-ukraińska na rubieżach południowo-wschodnich II RP wybuchła w latach trzydziestych XX w., kiedy to członkowie siatki Organizacji Ukraińskich Nacjonalistów na terenie Polski przeprowadzili klika spektakularnych mordów, m.in. 29 sierp-

2 G. Motyka, dz. cyt., s. 13. 
nia 1931 r. został zamordowany w Truskawcu Tadeusz Hołówko - poseł, który opowiadał się za pojednaniem polsko-ukraińskim ${ }^{3}$. Do najgłośniejszego mordu doszło w 1934 r., kiedy to nacjonaliści spod znaku OUN Bandera dokonali zamachu na ministra spraw wewnętrznych Bronisława Pierackiego ${ }^{4}$. Właściwie to zamachu na ministra Pierackiego dokonał Hryhorija Maciejka "Gonta”, związany z odłamem młodych OUN5. Sam Stefan Bandera został aresztowany w czerwcu 1934 r. przez policję polską i osadzony w więzieniu Świętego Krzyża na Łysej Górze.

Kolejny rozdział stosunków polsko-ukraińskich napisał wrzesień 1939 r. Wiadomo było, że Sowieci nie zgodzą się na powstanie Zachodnioukraińskiej Republiki Ludowej, zaś z drugiej strony w momencie ogłoszonej mobilizacji przez rząd RP tysiące Ukraińców wstąpiło w szeregi Wojska Polskiego. Wielu żołnierzy pochodzenia ukraińskiego zginęło $\mathrm{w}$ walce $\mathrm{w}$ szeregach Wojska Polskiego. Wielu zostało odznaczonych za odważną postawę na polu walki, np. płk Pawło Szandruk otrzymał Krzyż Virtuti Militari ${ }^{6}$.

Również drugi wróg Polski, III Rzesza, próbowała grać kartą ukraińską przeciwko Polakom na Kresach Wschodnich. Pod patronatem III Rzeszy zaczęto tworzyć oddziały pod nazwą Legion Ukraiński, który miał być użyty do akcji dywersyjnej przeciwko Polakom w celu siania zamętu i oczyścić tereny Polski południowo-wschodniej z elementu polskiego. Użycie przez III Rzeszę na szerszą skalę kureni tworzących LU zostało zahamowane z pobudek politycznych. Mianowicie 23 sierpnia 1939 r. został zawarty tajny protokół między ZSRR a III Rzeszą w sprawie strefy wpływów w Europie. Zawarty układ między mocarstwami zmienił stosunek Niemców do dążeń niepodległościowych Ukraińców. Stąd też, aby nie drażnić nowego sojusznika, Ukraińcy ograniczyli się do akcentów dywersyjnych bojówek spod znaku OUN, którzy atakowali polskie oddziały wojskowe. Co prawda Autor wspomina o atakach bojówek ukraińskich na terenie województw poleskiego i tarnopolskiego. Szkoda że Autor nie wspomniał, że często inspiratorami ataków dywersyjnych na cofających się żołnierzy WP byli działacze lub sympatycy Komunistycznej Partii Polski, np. w nocy z 28 na 29 września 1939 r. w Ko-

3 Hołówko Tadeusz, [w:] Kto był kim w Drugiej Rzeczypospolitej, red. J. M. Majchrowski przy współpracy G. Mazura i K. Stepana, Warszawa 1994, s. 297; T. Snyder, Tajna wojna. Henryk Józewski i polsko-sowiecka rozgrywka o Ukrainę, Kraków 2008, s. 113-114.

4 R. Potocki, Polityka państwa polskiego wobec zagadnienia ukraińskiego w latach 1930-1939, Lublin 2003, s. 109.

5 P. Sudopłatow, Wspomnienia niewygodnego świadka, Warszawa 1999, s. 38 i nast.

6 R. Torzecki, Polacy i Ukraińcy. Sprawa ukraińska w czasie II wojny światowej na terenie II Rzeczypospolitej, Warszawa 1993, s. 25. 
deńcu, pow. parczewski, zginął kpt. Bazyli Sobolew z 85. pp. Inspiratorami byli Bazyli i Władysław Kureszowie - sympatycy KPP rozwiązanej w 1938 r. Podobne akty dywersji ze strony Ukraińców były w innych częściach Podlasia. Również Kościół grekokatolicki wspierał akty przemocy wobec Polaków, m.in. popi z monastyru św. Onufrego z Jabłecznej urządzili w październiku 1939 r. nabożeństwo poświecone „pogrzebowi Polski”. Ubraną na biało-czerwono kukłę słomianą podpalono i wrzucono do rzeki Bug7. W kolejnych rozdziałach Autor podjął temat wzajemnych relacji po zajęciu Polski przez III Rzeszę i ZSRR. Nowa sytuacja polityczna i militarna postawiła Polaków i Ukraińców w odmiennej sytuacji. Niemcy od samego początku chcieli rozgrywać kartą ukraińską relacje między Polakami a Ukraińcami na korzyść tych drugich. Również Sowieci próbowali wykorzystać ludność ukraińską dla swych celów politycznych, kierując ostrze represji wobec Polaków. Po ataku III Rzeszy na ZSRR 22 czerwca 1941 r. odłam polityczny OUN Bandery rozpoczął akcję zbrojną przeciwko Sowietom, którzy pod ciosami Wehrmachtu cofali się na wschód. Po wejściu Niemców do Lwowa władzę w mieście przejęła grupa banderowców kierowana przez Jarosława Stećko. Ukraińcy zainspirowali pogrom Żydów w lipcu $1941 \mathrm{r}$. W pogromie wzięła udział milicja ukraińska oraz bojówkarze ukraińscy i okoliczni chłopi, którzy napojeni wódką wtargnęli do mieszkań Żydów i wyciągali ich na ulicę dokonując linczu. W tzw. Dniach Petlury zostało zabitych około 2 tys. osób ${ }^{8}$.

Na obszarach Ukrainy zajętej przez Niemców hitlerowcy wprowadzili brutalny reżim. Ostrze tej polityki zostało skierowane przeciwko Żydom, których postanowiono unicestwić. Zagłada całych grup społecznych wpływała demoralizująco na pozostałych mieszkańców tych ziem. Dodatkowym czynnikiem demoralizacji była łatwość wzbogacenia się mieniem pozostawionym. Dla miejscowej ludności była to nie lada pokusa, zwłaszcza dla biednej ludności kresowej, która przejmowała mienie, ubrania i przedmioty codziennego użytku, jak srebrne sztućce, porcelana, meble, które można było spieniężyć. Szkoda, że Autor nie uwzględnił w swojej pracy opracowania Włodzimierza Ważniewskiego ${ }^{9}$, w którym podjął on ważki problem relacji niemiecko-ukraińskich, podziemia polskiego i ukraińskiego wobec wydarzeń na froncie wschodnim 1943-1944. Opracowanie wpisuje się w temat podjęty

7 M. Bechta, Rewolucja mit bandytyzm. Komuniści na Podlasiu w latach 1939-1944, WarszawaBiała Podlaska 2000, s. 35.

8 G. Mazur, J. Skwara, J. Węgierski, Kronika 2350 dni wojny i okupacji Lwowa 1 IX 1939 - 5 II 1946, Katowice 2007, s. 218-219.

9 W. Ważniewski, Stracone nadzieje. Polityka władz okupacyjnych w Małopolsce Wschodniej 1939-1944, Warszawa 2009. 
przez Grzegorza Motykę. Kolejne rozdziały (s. 88-184) zostały poświęcone antypolskiej akcji UPA. Pierwszą akcję Ukraińcy spod znaku UPA przeprowadzili z 7 na 8 lutego 1943 r. na miasteczko Włodzimierzec. Szkoda, że Autor, omawiając powstanie Ukraińskiej Powstańczej Armii, nie zamieścił schematu struktury organizacyjnej UPA na Wołyniu - Dowództwa UPA „Północ” pod dowództwem płk. Dymitro Kljaczkiwśkyja, która przybliżyłaby czytelnikowi zrozumienie struktury partyzanckiej oddziałów bojowych Ukraińców.

Następnie sotnia Hryhorija Perehiniaka „Dowbeszka-Korobka” weszła do wsi Parośl, podszywając się pod oddział radzieckiej partyzantki, dokonując masakry ludności wsi. Warto podkreślić, że upowcy wymordowali mieszkańców w liczbie 173 osób przy pomocy siekier i innych tępych narzędzi, nie oszczędzając kobiet, dzieci i niemowląt ${ }^{10}$. W kolejnych rozdziałach Motyka poruszył problem wzmożonej akcji zbrojnej oddziałów UPA przeciwko Niemcom, Polakom i partyzantce komunistycznej powiązanej z Armią Czerwoną. Nasilenie akcji zbrojnych nastąpiło po zwycięstwie Armii Czerwonej pod Stalingradem na początku 1943 r. Władze ukraińskie uznały, że przyjdzie im walczyć o wolność z ZSRR lub Polską. W tym miejscu warto podkreślić, że szeregi UPA zostały zasilone przez dezerterów z policji ukraińskiej, która podlegała władzy niemieckiej, a potem zbiegła do oddziałów nacjonalistów ukraińskich. Aby zażegnać powstanie przeciwko władzy niemieckiej, Niemcy ściągnęli 25. dywizję wojsk węgierskich na Wołyń oraz próbowali grać polską kartą, wykorzystując istniejący antagonizm polsko-ukraiński. W miejsce zdezerterowanych ukraińskich policjantów powoływano Polaków, których dowództwo niemieckie napuszczało na Ukraińców; Polaków służących w 202. Schutzmannschaftsbataillon ${ }^{11}$, którego użyto do pacyfikacji wsi ukraińskich ${ }^{12}$.

Na początku wiosny 1943 r. Ukraińcy przystąpili do oczyszczania Wołynia $\mathrm{z}$ "elementu polskiego", który stanowił przed wybuchem drugiej wojny

10 W. Filar, Wydarzenia wolyńskie 1939-1944. W poszukiwaniu odpowiedzi na trudne pytania, Toruń 2008, s. 141.

11 Batalion 202 został utworzony w maju 1942 r. z polskiej policji granatowej w Kochanówce koło Dębicy. Dowódcą został Hauptmann Tschnader, zaś dowódcą polskim był mjr Policji Polskiej, Ignacy Kowalski. Oficerami byli: Z. Włoczewski, J. Kołodziej i B. Nowakowski (jako dowódcy kompanii), którzy zostali oddelegowani z Warszawy. Jednostka składała się z 3 kompanii po 120 ludzi. Komendę wydawano w języku niemieckim, szeregowi żołnierze byli ubrani $\mathrm{w}$ radzieckie mundury w kolorze khaki, stąd często byli nazywani zielonymi. Podaję za: W. Romanowski, ZWZ-AK na Wołyniu 1939-1944, Lublin 1993, s. 95-96.

12 W. Filar, Wotyń 1939-1944. Eksterminacja czy walki polsko-ukraińskie. Studium historyczno-wojskowe zmagań na Wotyniu w obronie polskości, wiary i godności ludzkiej, Toruń 2003, s. 38 i nast. 
światowej $16,6 \%{ }^{13}$. Oddziały OUN, dowodzone przez Iwana Łytwynczuka "Dubowyj”, rozpoczęły z całą konsekwencją akcję „oczyszczania” terenu z ludności polskiej. Akcja Ukraińców spowodowała reakcję ze strony polskiej. Polacy zaczęli organizować oddziały samoobrony, które często wspólnie z siłami niemieckimi lub sowieckimi stawiały opór oddziałom ukraińskim lub brały udział w akcjach odwetowo-pacyfikacyjnych, np. 19 kwietnia $1943 \mathrm{r}$. dokonano pacyfikacji wsi Krasny Sad, w której zginęło około 100 Ukraińców ${ }^{14}$. Poruszając problem odwetu ze strony policji polskiej i niemieckiej, Autor powinien wspomnieć, że w akcjach odwetowych wobec ukraińskich mieszkańców wsi uczestniczyli również Ukraińcy, np. w powiecie włodzimierskim brał udział Józef Sereda - Ukrainiec ożeniony z Polką, zaś inny Ukrainiec ze wsi Iwanie, Fedor, nazywany przez mieszkańców bolszewikiem, przekazywał informacje polskiemu podziemiu operującemu na Wołyniu o planach UPA, która za przekonania komunistyczne wymordowała cztery rodziny ukraińskie ${ }^{15}$.

Autor w rozdziale „Polska obrona i odwet” (s. 151-165) poruszył temat polskiego odwetu wobec masakry dokonanej przez UPA w dniach 11-12 lipca 1943 r. Na dowódcę odcinka Przebraże "Garnizon 100" został wyznaczony przez dowództwo AK plut. Henryk Cybulski „Harry”, zaś jego zastępcą Franciszek Żytkiewicz. Jak wspomina Cybulski, nie było zależności organizacyjnej pomiędzy pobliskimi ośrodkami Przebraże i Rafałówka, lecz łączyły je interesy wzajemnego bezpieczeństwa. Dobre przygotowanie przez Cybulskiego urządzeń obronnych w Przebrażu, m.in. rozmieszczenie oddziałów, wytrasowanie pierwszych linii obronnych, rowów dobiegowych, przeszkód i zasieków, rozmieszczenie broni maszynowej i odwodów przyniosło sukces Polakom $\mathrm{w}$ walce $\mathrm{z}$ oddziałami UPA.

Autor w recenzowanej pracy pominął zupełnie wydaną w 2014 r. książkę Cybulskiego ${ }^{16}$, która wpisuje się $\mathrm{w}$ tematykę poruszaną przez Motykę. W swoich wspomnieniach Cybulski odtworzył strukturę dowództwa "Garnizonu 100", czego nie ma w pracy Motyki, co w pewien sposób zubaża pracę.

Po przekroczeniu przedwojennej wschodniej granicy Polski w nocy z 3 na 4 stycznia 1944 r., polskie podziemie na Wołyniu znalazło się między sowieckim „młotem” a niemieckim „kowadłem”. W tym miejscu warto wspo-

13 Taki wskaźnik procentowy ludności polskiej zamieszkującej Wołyń w 1931 r. podaje W. Romanowski, dz. cyt., s. 27.

14 P. Bojarczuk, Tragedia Krasnego Sadu, http://www.volyn.com.ua/?rub=5\&article=0\&arch $=1371$.

15 W. Romanowski, dz. cyt., s. 94.

16 H. Cybulski, Krwawy Wołyń 43. Wspomnienia komendanta Przebraża, Warszawa 2014. 
mnieć, że Armia Czerwona prowadziła zajmowanie terenu Wołynia w pięciu etapach ${ }^{17}$.

Szkoda, że Motyka nie uzupełnił rozdziału poświeconego 27. Wołyńskiej Dywizji Piechoty AK, że już w lipcu 1943 r. polskie oddziały AK rozpoczęły przygotowywanie terenu do uruchomienia dużej jednostki partyzanckiej. Zaczęto od oczyszczania w powicie kowelskim terenu z oddziałów UPA. Stąd też na początku 1944 r. pomiędzy miastami: Kowel, Włodzimierz i Luboml powstała możliwość do odtworzenia według przedwojennej numeracji WP 27. Dywizji Piechoty, której jednostki stacjonowały przed 1 września 1939 r. w Kowlu, Łucku i Włodzimierzu ${ }^{18}$.

W tym miejscu chciałbym nieco rozwinąć i sprostować stosunek Obozu Narodowego do kwestii ukraińskiej. Autor w rozdziale „W Małopolsce Wschodniej mamy wojnę" (s. 199-213) pisze, że Stronnictwo Narodowe i "Szaniec" przeczyły w ogóle istnieniu "problemu ukraińskiego", twardo stojąc na "asymilacji narodowej” ${ }^{19}$. Odmienne stanowisko wobec kwestii poruszanej przez Grzegorza Motykę znajdujemy w dokumencie „Wytyczne programowe ruchu narodowego w Polsce. Program Stronnictwa Narodowego" 20, z którego nie skorzystał Autor recenzowanej książki.

Obóz Narodowy twierdził, że nie ma narodu ukraińskiego, tylko istnieje separatystyczny ruch ukraiński stworzony przez Niemców i Austrię dla rozbicia Polski i Rosji. Uważali ludność ruską za polską, która powinna mieć polskie poczucie narodowe. Narodowcy twierdzili, że ukraiński ruch polityczny został stworzony sztucznie i dąży on do stworzenia sztucznych różnic i nienawiści do Polaków. Szeroko pojęty Obóz Narodowy w celu rozwiązania kwestii ukraińskiej stawiał za cel ukaranie zbrodniarzy winnych zbrodni, morderstw oraz wszystkich współwinnych osób; zlikwidowanie ruchu ukraińskiego, ukraińskich instytucji, tajnych organizacji i przywódców,

174 stycznia 1944 r. została przekroczona granica Polski z 1939 r. w rejonie Sarn; 2 lutego I Korpus Kawalerii zajął Równe, Ostróg, Łuck i przedmieścia Dubna, a 3 lutego - Zdołbunów. 19 marca zepchnięto obronę niemiecką z linii Styru w kierunku Kowla, wyzwolono Krzemieniec i resztę Dubna; Niemcy opuścili Kowel 6 lipca, lecz nadal utrzymywali się na linii Turii. W daniach 18-20 lipca wyparto Niemców z obszaru pomiędzy Turią a Bugiem, w tym również z miast Włodzimierz i Luboml. Najpóźniej - 21 lipca, została zajęta ostania reduta niemieckiej obrony na Wołyniu, miasteczko Uściług, szerzej patrz: Łucko-rówieńska operacja 1944 r., [w:] Encyklopedia II wojny światowej, red. W. Biegański, Warszawa 1975, s. 300 .

18 I. Caban, Z. Mańkowski, Zwiq̨zek Walki Zbrojnej i Armia Krajowa w Okręgu Lubelskim 1939-1944, cz. I, Lublin 1968, s. 186-188.

19 G. Motyka, dz. cyt., s. 199.

20 Opublikowany w: Narodowcy. Myśl polityczna i społeczna Obozu Narodowego w Polsce w latach 1944-1947, red. L. Kulińska, Warszawa - Kraków 2001, s. 43-55. 
likwidację Cerkwi prawosławnej. $\mathrm{W}$ to miejsce miano prowadzić akcję wychowawczą, kolonizację polską na terenach wschodnich Polski, stworzenie silnej sieci polskiego szkolnictwa, Kościoła i duszpasterstwa. Ponadto, Polacy mieli skolonizować te ziemie, stworzyć silny kordon nad rzeką Zbrucz, by nie dopuścić galicyjskich działaczy ukraińskich do wschodnich prowincji ${ }^{21}$. Również co do terenów rdzennych na Ukrainie, narodowcy głosili przywrócenie własności prywatnej, wolności osobistej i bezpieczeństwa. Miano wysiedlić wszystkich kolonistów rosyjskich, mongolskich itd., a osiedlić ludność polską z całego obszaru Rosji. Miano stworzyć polską administrację, szkoły i parafie polskie. Postulowano likwidację instytucji i działaczy komunistycznych ${ }^{22}$. W programie uwypuklano, że narodowcy nie dopuszczą do odnowienia Cerkwi, którą uważano za współwinną ludobójstwa Polaków na Wołyniu w latach 1943-1944. Narodowcy nie zamykali drogi co do kultywowania własnej tradycji, języka, religii przez Ukraińców. Mieli oni również mieć pełnię praw politycznych, ale pod warunkiem bezwzględnej lojalności wobec państwa polskiego ${ }^{23}$. W podobnym tonie na temat rozwiązania kwestii ukraińskiej przez Polaków wypowiadał się inny ideolog Obozu Narodowego, Adam Doboszyński ${ }^{24}$.

Wzorując się na wydarzeniach na Wołyniu, Ukraińcy rozpoczęli czystki w Galicji Wschodniej. Ostrze uderzenia bojówek ukraińskich zostało skierowane w grupę leśników, którzy w zależności od pełnionej służby i swobodnego przemieszczania się $\mathrm{w}$ terenie mogli być sympatykami lub zagrożeniem dla partyzantów. W Galicji Wschodniej do znanych oddziałów UPA operujących na terenie Galicji Wschodniej należał oddział noszący kryptonim "Siromanci" pod dowództwem Dymytro Karpenko. Rozkazem dowództwa UPA oddział został wysłany na rajd na teren Galicji Wschodniej i dotarł do Lubaczowa. W tym miejscu warto wspomnieć, że oddział "Siromanci" współpracował z dywizją SS "Galizien”, np. ukraińscy partyzanci udzielili pomocy żołnierzom z dywizji SS „Galizien”, którzy wpadli w zasadzkę AK pod Hutą Pieniacką w lutym 1944 r. Tylko dzięki wsparciu żołnierzy z sotni "Siromanci" oddział nie uległ całkowitej zagładzie. Działał on do 1946 r., kiedy został rozwiązany.

21 Narodowcy. Myśl polityczna i społeczna..., s. 51.

22 Tamże.

23 Stronnictwo Narodowe - podłoże ideowe, wytyczne programowe, [w:] Narodowcy. Myśl polityczna i społeczna..., s. 56 .

24 Szerzej patrz: B. Nitschke, Czasopismo „Walka" jako wyraz poszukiwania przez Adama Doboszyńskiego nowej drogi politycznej na emigracji, [w:] Prasa Narodowej Demokracji od roku 1939 do początku XXI wieku, red. A. Dawidowicz, E. Maj, t. 2, Lublin 2011, s. 50. 
W rozdziale poświęconym dywizji SS "Galizien” (s. 256-271) Autor słusznie zauważył, że udział żołnierzy w tłumieniu powstania w Warszawie w sierpniu 1944 r. to wymysł samych mieszkańców Warszawy, którzy byli przekonani, że mordów dokonują żołnierze z dywizji „Hałyczyna”. Mylono ich z brygadą Rosyjskiej Armii Wyzwoleńczo-Ludowej (RONA) Bronisława Kamińskiego ${ }^{25}$, która wzięła udział w tłumieniu powstania na Ochocie. W tym miejscu warto uzupełnić, że do tłumienia powstania został sformowany z nieżonatych żołnierzy, w Częstochowie, liczący 1700 osób pułk, który przybył do Warszawy na Okęcie 3 sierpnia 1944 r. ${ }^{26}$ Następnie pułk dotarł do ulicy Chałubińskiego. Żołnierze tego pułku walczyli z powstańcami $\mathrm{w}$ prostokącie Alei Jerozolimskich, Towarowej, Krochmalnej i Żelaznej 21 sierpnia $1944 \mathrm{r}$. W walkach z powstańcami zginął dowódca pułku RONA, mjr Jurij Frołow ${ }^{27}$. Następnie pułk został wycofany w rejon Puszczy Kampinoskiej ${ }^{28}$.

Kolejnym terenem zmagań polsko-ukraińskich była Lubelszczyzna. Już w okresie okupacji niemieckiej teren ten był ze względu na położenie idealnym miejscem na realizację planu „ostatecznego rozwiązania”. Poza eksterminacją ludności polskiej prowadzoną przez szefa dystryktu lubelskiego

Bronisław Kamiński ur. 16 czerwca 1899 r. w Witebsku. Był synem Polaka i Niemki. Mieszkał w Piotrogrodzie, gdzie studiował chemię. Po uzyskaniu dyplomu inżyniera pracował w fabryce farb i lakierów. W 1929 r. występował przeciwko kolektywizacji rolnictwa. W 1935 r. został aresztowany przez NKWD, oskarżano go o kontakty z wywiadami polskim i niemieckim. Po wybuchu wojny niemiecko-radzieckiej w czerwcu 1941 r., Kamiński został nauczycielem technikum leśnego w Brasowie, małej miejscowości pod Łoktiem. Utworzył Narodowo-Socjalistyczną Partię Rosji. Po śmierci Woskobojnikowa Kamiński został starostą i dowódcą milicji. Dzięki poparciu gen. Schmidta stworzył oddział liczący 1400 żołnierzy. 19 lipca 1942 r. z rąk gen. Schmidta Bronisław Kamiński otrzymał generała brygady, był to tytuł, a nie stopień. Jego żołnierze nosili niemieckie mundury, które na ramieniu miały krzyż z literami RONA pisanymi cyrylicą. Następnie jego brygada została przerzucona na Białoruś. 27 stycznia 1944 r. z rąk gen. Burgdorfa otrzymał Krzyże Żelazne II i I klasy jednocześnie. Następnie po awansowaniu Kamińskiego na Waffen Brigadeführera i generała-majora, brygada została wcielona do SS, a nie do Waffen SS. Po niepowodzeniach w walkach w Warszawie, a potem w Puszczy Kampinoskiej Kamiński został aresztowany prawdopodobnie z polecenia samego Himmlera i po procesie sądowym został stracony 28 sierpnia 1944 r. Opracowano na podstawie: J. Thorwald, Iluzja. Żotnierze radzieccy w armii Hitlera, Warszawa 1994, s. 83; Dziennik wojenny generała SS Ericha von dem Bacha, "Acta Universitatis Vratislaviensis” 1987, t. XI, s. 235; J. Gdański, Brygada Kamińskiego, „Wojskowy Przegląd Historyczny" 1994, nr 3, s. 391; R. Michaelis, Die russische Volksbefreiungsarmee RONA 1941-1944, Erlangen 1992, s. 49; Z. Rudny, Brygada RONA, „Wojskowy Przegląd Historyczny" 1997, nr 1-2, s. 224-241.

R. Bielecki, W zasięu PASTy, Warszawa 1994, s. 273.

Szerzej patrz: Z. Rudny, dz. cyt., s. 237 i nast. 
Odilo Globocnika, Ukraińcy, którzy byli w mniejszości na terenie Lubelszczyzny, byli faworyzowani przez Niemców. Pod patronatem Ukraińskiego Centralnego Komitetu Ukraińcy rozwinęli działalność społeczną-kulturalną. Na teren Lubelszczyzny przybyło z Galicji i Wołynia kilka kureni pod dowództwem Mirosława Onyszkewycza "Oresta”. W rozdziale „Metropolita Andrzej Szeptycki: katecheza w czasach pogardy" (s. 313-329) Autor odniósł się do postawy Kościoła grekokatolickiego wobec wydarzeń polsko-ukrainskich lat 1939-1944. O ile zbrodnie popełnione przez bojówki spod znaku OUN-UPA na Polakach metropolita Szeptycki potępiał, wzywał Ukraińców do obrony życia i mienia ludności zagrożonej aktami terroru ${ }^{29}$, to kapelanów, którzy pełnili posługę duszpasterską w dywizji SS „Galizien” rozgrzeszał i usprawiedliwiał. W dywizji SS "Galizien” Szeptycki widział zalążek przyszłej ukraińskiej armii, która miała być siłą zbrojną wolnej Ukrainy.

Kolejne rozdziały (s. 330-420) Motyka poświęcił ukazaniu relacji w stosunkach między UPA a polską partyzantką, wywołane wkroczeniem Sowietów na ziemie polskie. Interesująco opisana jest w kontekście ukraińskim Akcja „Burza”. Autor w podrozdziale „Istriebitielnyje Bataliony” (s. 337-339), tzw. grupy wsparcia, poruszył problem udziału Polaków w szeregach milicji pomocniczej NKWD, który do dzisiaj wzbudza kontrowersje wśród badaczy stosunków polsko-ukraińskich. Toczą się dyskusje na temat: Czy Polacy byli kolaborantami Sowietów w zwalczaniu partyzantki ukraińskiej, czy żołnierzami „sojuszniczej armii"? Zwłaszcza w meldunkach UPA widać, że IB, w których służyli Polacy były poważnym zagrożeniem ${ }^{30}$. Żołnierze podziemia ukraińskiego traktowali Polaków służących w IB jako sowieckich kolaborantów. Jeden z dowódców UPA na Wołyniu, „Hryć” (N.N.), pisał o nich: „[Polacy] poszli na bezkrytyczną współpracę i służbę dla NKWD (...). Dlatego przeciwko nim przyjmujemy te same działania, co wcześniej. Należy przeprowadzić zwiad - gdzie i jakie siły wroga są skupione, a następnie je niszczyć" 31 .

Szkoda, że Autor pominął cel powstania IB. Powstały z inicjatywy lokalnych struktur partyjnych po zajęciu terenów przez Sowietów. Oddziały IB

29 Szerzej patrz: List pasterski metropolity Szeptyckiego do duchowieństwa i wiernych, "Znak" 1988, nr 9, s. 78.

30 G. Motyka, Zwalczanie podziemia antykomunistycznego przez władze sowieckie - podobieństwa i różnice sytuacji w poszczególnych republikach związowych, [w:] G. Motyka, R. Wnuk, T. Stryjek, A. F. Baran, Wojna po wojnie. Antysowieckie podziemie w Europie Środkowo-Wschodniej w latach 1944-1953, Gdańsk - Warszawa 2012, s. 216-217.

31 G. Motyka, R. Wnuk, Pany i rezuny. Wspótpraca AK-WiN i UPA 1945-1947, Warszawa 1997, s. 67. 
były formowane z miejscowej ludności i zajmowały się ochroną miejscowości i majątku państwowego, ochraniały kołchozy, kluby, spółdzielnie, szkoły. Miały utrudnić partyzantom korzystanie z pomocy mieszkańców wsi. W mieście rejonowym dodatkowo stacjonował pluton szturmowy IB, który miał za zadanie wspierać sowieckie akcje oczyszczające. Warto podkreślić, że powodem wstępowania Polaków w struktury IB, poza strachem przed deportacją do łagrów na Syberię czy przymusowym wcieleniem do armii Berlinga, była przede wszystkim obrona Polaków przed napadami partyzantów UPA. Szkoda, że Autor ze szkodą merytoryczną książki pominął artykuł Tomasza Balbusa ${ }^{32}$ dotyczący polskich IB. Warto podkreślić, że niektórzy oficerowie AK zostawali dowódcami IB, np. kpt. Zygfryd Szynalski „Tryk”, wybitny oficer Kedywu w Inspektoracie Brzeżany AK, w czasie „Burzy” dowodzący 2. kompanią (około 100-120 ludzi) 51. pp AK, który na początku sierpnia 1944 r. ujawnił się w Brzeżanach, został zaraz wyznaczony na dowódcę tamtejszego IB. Batalion podlegał bezpośrednio placówce NKWD w Brzeżanach $^{33}$. Autor również nie pokusił się o przedstawienie skali tego zjawiska. Według danych $\mathrm{z}$ dokumentów ukraińskich wynika, że w połowie 1945 r. w IB służyło 18 tys. osób oraz dodatkowo 26 tys. w pomocniczych grupach współdziałania (wówczas już w większości Ukraińców). Ich działania wspomagało 175 rezydentów, ponad 1100 agentów, około 10 tys. informatorów sowieckich służb bezpieczeństwa oraz co najmniej kilkadziesiąt specgrup operacyjnych, złożonych z funkcjonariuszy i współpracowników NKWD i NKGB, udających oddziały UPA (tzw. oddziały pozorowane wykorzystywane były również w Polsce do zwalczania partyzantki antykomunistycznej). Łącznie w latach 1944-1950 w IB służyło około 50 tys. Polaków i Ukraińców ${ }^{34}$. Do walki z polskim i ukraińskim podziemiem zbrojnym komuniści w swoim ręku posiadali poważną siłę.

W ramach prowadzonej akcji „Burza” dowódcy AK przekładali bowiem cele militarno-polityczne tej operacji nad ochronę polskiej ludności przed ukraińskimi bandami, co Autor wyraźnie podkreśla. Zupełnie inne stanowisko zajęli narodowcy i partyzantka narodowców, która zakładała, że bardziej istotna powinna być ochrona własnej ludności. Szczególnie komentarza historycznego wymaga sprawa wyjaśnienia ataku oddziałów Narodowych Sił Zbrojnych na ukraińską wieś Wierzchowiny pod dowództwem kpt./mjr. Mie-

32 T. Balbus, Polskie "Istriebitielnyje Bataliony” NKWD w latach 1944-1945, „Biuletyn IPN” 2002, nr 6, s. 73.

34 T. Balbus, dz. cyt., s. 75. 
czysława Pazderskiego "Szarego" 6 czerwca 1945 r. Autor, w pełni przekonany o słuszności swojej tezy, jednoznacznie wydaje wyrok, że masakry mieszkańców tej wsi dokonały oddziały NSZ pod dowództwem "Szarego": "6 czerwca partyzanci NSZ wkroczyli do uchodzącej za sprzyjającą komunistom ukraińskiej wsi Wierzchowiny i dokonali masakry jej mieszkańców" (s. 371). Dalej Motyka na łamach recenzowanej książki stwierdza: „Po latach odpowiedzialność za mord w Wierzchowinach próbowano zrzucić z NSZ na udających partyzantów funkcjonariuszy UB. W świetle choćby zacytowanych dokumentów należy stanowczo powiedzieć, że «teorie» pod względem naukowym są warte tyle samo, co twierdzenia, iż na Wołyniu Polaków nie zabijała UPA, tylko przebrani sowieccy partyzanci" (s. 372). Szkoda, że Autor nie podał, jakie dokumenty cytuje. Jedynie w sprawie Wierzchowin powołuje się na tekst Mariusza Zajączkowskiego ${ }^{35}$. Autor również nie uwzględnił badań nad sprawą Wierzchowin innych badaczy: Marcina Zaborskiego ${ }^{36}$, Anny Grażyny Kister ${ }^{37}$, Mirosława Piotrowskiego ${ }^{38}$, którzy w swoich tekstach stawiają hipotezy, że niekoniecznie mord na mieszkańcach ukraińskiej wsi Wierzchowiny był dziełem żołnierzy NSZ. Szczególnie interesującej rekonstrukcji wydarzeń we wsi Wierzchowiny dokonał Mirosław Piotrowski, który wykorzystał materiały zdeponowane w Centralnym Archiwum Wojskowym w Rembertowie (m.in. znajdują się tam opisy działań bojowych pododdziałów 98. pułku pogranicznego NKWD, likwidujących bandy-grupy „AK" prowadzone przez "Sokoła” $\mathrm{i}$ „Szarego" w rejonie Wierzchowin i Huty w dniach 6-11 czerwca 1945 r.) oraz raport i protokół Komisji ukazującej opis wydarzeń w Wierzchowinach, które znajdują się w Archiwum Akt Nowych, zaś pełny tekst pracy Komisji - w Rosyjskim Wojskowym Archiwum Państwowym w Moskwie. Materiały te nie do końca rzucają podejrzenia, że zrobiły to oddziały NSZ. Grzegorz Motyka powiela propagandowy slogan komunistów, którzy w celu zdyskredytowania w oczach Polaków i Ukraińców żołnierzy NSZ „został puszczony” do społeczeństwa, przypisując masakrę wsi Wierzchowiny oddziałom NSZ pod dowództwem kpt. „Szarego”. Do takiego obrazu działań żołnierzy NSZ, przypisującego

M. Zajączkowski, Spór o Wierzchowiny. Działalność oddziałów Akcji Specjalnej (Pogotowia Akcji Specjalnej) NSZ w powiatach Chetm, Hrubieszów, Krasnystaw i Lubartów na tle konfliktu polsko-ukraińskiego (sierpień 1944 roku - czerwiec 1945 roku), „Pamięć i Sprawiedliwość. Pismo Instytutu Pamięci Narodowej" 2006, nr 1, s. 282-287.

36 M. Zaborski, Zbrodnia nie popetniona przez NSZ, "Gazeta Polska" z 15 września 1994 r., s. 1-2.

37 A. G. Kister, Wierzchowiny, „Nasza Polska” z 4 lutego 2003 r., s. 10-11.

38 M. Piotrowski, Narodowe Siły Zbrojne na Lubelszczyźnie 1944-1947, Lublin 2009, s. 66-93. 
dzieło egzekucji Ukraińców z Wierzchowin, przyczynił się Roman Jaroszyński „Roman”, który poszedł na współpracę z komunistami i mówił to, co było wygodne dla propagandzistów. Trudno wierzyć w to, co pisał „Roman", który bezpośrednio nie brał udziału w pacyfikacji tej wsi, jedynie zabezpieczał wylot ulicy: „Ja przez cały czas akcji we wsi Wierzchowiny byłem na szosie" 39 . Trudno opierać się na zeznaniach Jaroszyńskiego, skoro on sam przede wszystkim chciał ratować własne życie, idąc na pełną współpracę z komunistami. Zeznawał wszystko, co sąd wojskowy chciał usłyszeć. Poza tym publicznie złożył samokrytykę, chwalił ówczesny ustrój oraz potępił rząd polski na uchodźstwie. Autor, zanim wydał wyrok obwiniający żołnierzy NSZ o dokonanie masakry mieszkańców wsi Wierzchowiny, powinien pamiętać o ściśle tajnym rozkazie szefa MBP Stanisława Radkiewicza z 4 grudnia 1945 r., który został skierowany do placówek UB szczebli wojewódzkiego i powiatowego o tworzeniu oddziałów pozorowanych, które, podszywając się pod oddziały podziemia niepodległościowego, dokonywały na ich konto akcji. Potem odpowiedzialnością miano obciążać podziemie antykomunistyczne ${ }^{40}$. Być może w Wierzchowinach oddziały NSZ dokonały likwidacji 15-19 osób, najbardziej szkodliwego elementu, który współpracował z UB, NKWD i UPA. Zaś po wyjściu ze wsi oddziałów NSZ wkroczyły oddziały pozorowane, składające się z pracowników UB, żołnierzy NKWD, które dokonały masakry 194 mieszkańców Wierzchowin ${ }^{41}$. Jedno jest pewne, że 6 czerwca 1945 r. do ukraińskiej wsi Wierzchowiny wkroczył oddział NSZ, dokonując egzekucji jej mieszkańców, którzy byli szczególnie niebezpieczni (konfidenci, informatorzy, pracownicy UB, NKWD i UPA) dla partyzantów. Niemniej, ostateczne rozstrzygnięcie, czy zginęło tam 18-20 osób czy 10 razy więcej, wykaże dopiero ekshumacja planowana przez lubelski IPN.

Recenzowaną książkę zamykają rozdziały poświęcone przesiedleniom ludności polskiej i ukraińskiej przez władze sowieckie (s. 378-399), podziemiu ukraińskiemu w Polsce w latach 1945-1946 (s. 400-420), akcji „Wisła" (s. 421-445) i próbie bilansu (s. 446-468). Przygotowania do wysiedlenia Ukraińców w planowaniu komunistów rozpoczęły się już w 1946 r. Zapłonem do praktycznej realizacji planu przesiedlenia ludności ukraińskiej na tereny północno-zachodniej Polski stał się zamach na gen. Karola Świerczew-

39 Archiwum Instytutu Pamięci Narodowej Lublin (AIPN Lu), sygn. 06/355, t. 5, Protokół przesłuchania Romana Jaroszyńskiego, k. 119.

40 Ludzie Bezpieki w walce z Narodem i Kościołem. Służba Bezpieczeństwa w Polskiej Rzeczypospolitej Ludowej w latach 1944-1978 - Centrala, oprac. M. Piotrowski, Lublin 2000, s. 313.

41 M. Piotrowski, dz. cyt., s. 72. 
skiego 28 marca 1947 r. Następnego dnia zebrało się Biuro Polityczne PPR, m.in. w zebraniu udział wzięli Bolesław Bierut i Władysław Gomułka, które śmierć gen. Świerczewskiego postanowiło wykorzystać politycznie do rozprawy z partyzantką UPA. Wzorując się na sowieckim planie wysiedlenia ludności wrogiej komunistom, działania polskie zostały uzgodnione z rządem ZSRR i Czechosłowacji. Do przeprowadzenia działań wysiedlenia ludności ukraińskiej została powołana Grupa Operacyjna „Wisła”, którą dowodził gen. Stefan Mossor. Autor, omawiając w recenzowanej pracy akcję „Wisła", pominął fakt, że z dowództwami wojskowymi współpracował Zarząd Centralny Państwowego Urzędu Repatriacyjnego. Oddziały PUR w terenie miały za zadanie sporządzić karty przesiedleńców, zapewnić suchy prowiant oraz przygotować całodzienny posiłek dla rodzin ukraińskich oczekujących na swój transport ${ }^{42}$. W tym miejscu warto podkreślić, że w czasie wysiedlenia panował chaos. Część rodzin ukraińskich przekupywała żołnierzy, wracała na swoje miejsce i dokonywała zniszczenia mienia, urządzeń gospodarczych lub podpalała swoje gospodarstwa. Zjawisko to przybrało, m.in. w powicie bialskim, takie rozmiary, że zaczęło niepokoić urzędników województwa lubelskiego. Kolejnym skutkiem przesiedlania ludności ukraińskiej była masowa ucieczka młodzieży do lasu, która zasilała oddziały UPA. Często sama ludność zostawiała gospodarstwa i uciekała do lasu. Warto podkreślić, że każdy etap akcji „Wisła” regulowały instrukcje. Ludność ukraińska w zależności od stopnia zagrożenia została podzielona na trzy kategorie: A, B i C. Najgorszą mieli Ukraińcy - kategorię A. Byli traktowani jako najwięksi wrogowie Polski i otrzymywali na miejscu przesiedlenia najgorsze gospodarstwa. Kategorię B otrzymywali Ukraińcy, którzy byli notowani przez wywiad UB i wojskowy. Najczęściej byli to sympatycy UPA, którzy pozytywnie wyrażali się o partyzantce ukraińskiej. Ukraińcy, którzy przez władze wojskowe zostali uznani za najmniej szkodliwy element, otrzymywali kategorię C i mogli na terenach Polski północnej czy zachodniej otrzymać dużo lepsze poniemieckie gospodarstwa ze sprzętem rolniczym ${ }^{43}$. Często $\mathrm{w}$ trakcie zasiedlania opuszczonych gospodarstw ukraińskich przez Polaków dochodziło do dramatycznych scen, gdzie pojawiali się uciekinierzy ukraińscy, którzy wracali na swoje siedliska. W miejscowości Połoski grupa kontrolna natknęła się na Tomasza Romaniuka - Ukraińca, który zaatakował kijem sołtysa,

42 Archiwum Akt Nowych (AAN), sygn. I/4, ZC PUR, Biuro dyrektora, Kancelaria tajna i teczka sprawozdań z kontroli placówek PUR współpracujących z akcją „Wisła”, Instrukcja ZC PUR, maj 1947 r., k. 4.

43 A. Tłomacki, Akcja "Wisła” w powiecie bialskim na tle walki politycznej i zbrojnej w latach 1944-1947, Biała Podlaska - Warszawa 2003, s. 192. 
ORMO-wca i żołnierza WP. Ten w akcie samoobrony zastrzelił z automatu Ukraińca ${ }^{44}$. Podobne przykłady można by mnożyć. Kolejnym problemem była współpraca Polaków mieszkających we wsiach, z których miano wysiedlić rodziny ukraińskie. Polacy wskazywali grupom kontrolnym ukrywających się Ukraińców lub tych, którzy w jakiś sposób uniknęli wysiedlenia. Takie zachowanie często rodziło konflikt polsko-ukraiński w mikroskali.

W sumie z terenu powiatu bialskiego do 21 lipca $1947 \mathrm{r}$. wywieziono około 9600 Ukraińców ${ }^{45}$. Grzegorz Motyka, omawiając w rozdziale akcję "Wisła" (s. 421-445), nie omówił jej drugiej strony, mianowicie rodzenia się kryminogennych zachowań pracowników i wojskowych, którzy odpowiadali za przemieszczenie takiej masy ludzi w inne regiony Polski.

Takie masowe spędzenie ludności z różnych wsi rodziło ogromne zamieszanie i bałagan, zwłaszcza na stacjach kolejowych. Przyczyniło się to do rozwoju łapówkarstwa, zwłaszcza wśród obsługi punktu załadunkowego. Oddelegowani pracownicy PUR na masową skalę rozwinęli nielegalny handel dobrami, które z założenia winny być przeznaczone dla każdego z wysiedlanych. W praktyce, ten kto dysponował większą gotówką mógł liczyć na więcej siana dla zwierząt, lepsze jedzenie itd. ${ }^{46}$

Ciągły brak dóbr konsumpcyjnych na rynku sprawił, że pracownicy PUR nieustannie kombinowali, kradli, wchodzili w nieformalne układy z wysiedlonymi Ukraińcami. Z punktu naukowego ciekawym rozdziałem jest próba bilansu konfliktu polsko-ukraińskiego w latach 1943-1947 (s. 446-468). Grzegorz Motyka jest znanym badaczem stosunków polsko-ukraińskich nie tylko w Polsce, ale również w Europie. Stąd jego ustalenia liczby ofiar ${ }^{47}$, które przytacza są oparte na dogłębnych badaniach historycznych. Dane przytoczone przez Autora zadają kłam zwłaszcza niektórym badaczom ukraińskim jakoby liczba ofiar po stronie polskiej była taka sama jak po stronie ukraińskiej. Również po stronie polskiej często się słyszy, jakoby miało zginąć z rąk Ukraińców około 180-200 tys. Polaków, co nie ma potwierdzenia w badaniach, zaś liczby przytaczane $w$ mediach są podawane raczej dla wywołania sensacji.

Reasumując, po pierwsze, nieodpowiednia jest w moim przekonaniu forma publikacji, niedająca $\mathrm{w}$ dużej mierze możliwości skonfrontowania

\footnotetext{
44 AIPN Lu, sygn. 00231/92, t. 4, Akcja „Wisła”, Informacja o zabiciu Ukraińca Tomasza Romaniuka mieszkańca wsi Połoski w gm. Piszczac (Chotyłów, 21 lipca 1947 r.), k. 280.

45 Centralne Archiwum Wojskowe (CAW), sygn. 60/571/582, 47. pp, wykaz ilościowy ludności wysiedlonej i pozostawionej na miejscu z rejonu odpowiedzialności 11. kombinowanego pp, k. 175-176.

46 A. Tłomacki, dz. cyt., s. 204.

47 G. Motyka, Od rzezi wołyńskiej..., s. 446-450.
} 
twierdzeń Autora z materiałem źródłowym i innymi opracowaniami. Forma opracowania, jaką przyjął Autor, jest w moim przekonaniu nie do końca odpowiednia. Nie jest to bowiem książka naukowa, raczej skłaniałbym się do określenia publikacji mianem popularnonaukowa. Myślę, że do przedstawiania tak poważnej tematyki jak stosunki polsko-ukraińskie w latach 1943-1947 bardziej adekwatna byłaby ta pierwsza. Pozwalałoby to bardziej precyzyjnie uzasadnić wnioski wyciągane przez Autora, a jednocześnie odsyłałoby czytelnika do materiału źródłowego, na którym się opierał. Tymczasem do rąk otrzymujemy książkę, w której znajdują się tylko wybiórcze przypisy, i to jeszcze umieszczone na końcu książki, co utrudnia lekturę. Autor pisze, że zamieszcza przypisy jedynie tam, gdzie jest to niezbędne, nie informuje czytelnika, co konkretnie miał na myśli. Wydaje się, że zajmując się tak trudnym tematem, budzącym wiele sporów i kontrowersji, należy w jak największym stopniu trzymać się aparatu naukowego, co jednak w wielu momentach sprawia Grzegorzowi Motyce trudności.

Kolejnym mankamentem jest używanie zaskakująco dużej liczby eufemizmów, m.in. zastępowanie słowa ludobójstwo określeniami o mniej negatywnym charakterze. Szczególnie zaskakuje to w podsumowaniu, gdzie Autor wydaje się zmierzać do nazwania tego po imieniu, zatrzymując się w ostatniej chwili. Po trzecie, w publikacji naukowej Grzegorza Motyki, razi zbyt jednostronne ujęcie stosunku obozu narodowego do Ukraińców i UPA. Moim zdaniem Autor zbyt fragmentarycznie potraktował w recenzowanej książce stosunek UPA do Żydów, co w owym czasie stanowiło kwestię bardzo istotną.

Mimo wyżej wymienionych zastrzeżeń, nie oznacza to jednak w żadnej mierze, że publikację G. Motyki należy odrzucić. Autor niejednokrotnie bowiem trafnie analizuje ważne elementy stosunków polsko-ukraińskich i w wielu miejscach jego książka podejmuje problemy dotyczące stosunków polsko-ukraińskich z lat 1943-1947 wręcz o charakterze pionierskim. Duży ukłon należy się wydawnictwu: Wydawnictwu Literackiemu, które wydało pracę $\mathrm{w}$ solidnej twardej oprawie i przyjemnym dla oka drukiem. Przyjemna lektura tej książki jest dużą zasługą korektorów, którzy pozbawili książkę literówek, błędów składniowych i powtórzeń tak często spotykanych w tego typu opracowaniach.

Wiesław Charczuk, dr historii, pracuje w Zespole Szkół w Krzesku-Królowej Niwie, naukowo związany z Instytutem Nauk Społecznych i Bezpieczeństwa Uniwersytetu Przyrodniczo-Humanistycznego w Siedlcach.

e-mail: acharczuk5@o2.pl 